Article

\title{
Shaking Rate during Production Affects the Activity of Escherichia coli Surface-Displayed Candida antarctica Lipase A
}

\author{
Chen-Fu Chung ${ }^{1}$, Shih-Che Lin ${ }^{1}$, Tzong-Yuan Juang ${ }^{2, *(D)}$ and Yung-Chuan Liu ${ }^{1, *(D)}$ \\ 1 Department of Chemical Engineering, National Chung Hsing University, Taichung 402, Taiwan; \\ hahahaandy@gmail.com (C.-F.C.); leo83873@yahoo.com.tw (S.-C.L.) \\ 2 Department of Cosmeceutics, China Medical University, Taichung 40402, Taiwan \\ * Correspondence: tyjuang@mail.cmu.edu.tw (T.-Y.J.); ycliu@dragon.nchu.edu.tw (Y.-C.L.)
}

Received: 5 March 2020; Accepted: 30 March 2020; Published: 1 April 2020

check for updates

\begin{abstract}
In this study, a surface-display system was applied for the expression of lipase A in an $E$. coli expression system. Since the target protein was exposed on the cell membrane, the shaking rate during culturing might have increased the oxygen mass transfer rate and the shear stress, both of which would be detrimental to the surface-displayed protein. The shaking rate did indeed have an effect on the properties of the surface-displayed lipase A from Candida antarctica (sdCALA). When cultivated at a shaking rate of less than $50 \mathrm{rpm}$, the specific activity of sdCALA was low, which was due to the limited amount of dissolved oxygen. When the shaking rate was greater than $100 \mathrm{rpm}$, the specific activity decreased as a result of shear stress. When cultivating CALA and sdCALA at various temperatures and values of $\mathrm{pH}$, both proteins displayed the same activity profile, with the optimum conditions being $60^{\circ} \mathrm{C}$ and $\mathrm{pH}$ 6. A kinetic study revealed that the sdCALA cultivated at $100 \mathrm{rpm}$ gave a higher value of $v_{m}(0.074 \mu \mathrm{mol} / \mathrm{mL} / \mathrm{min})$ and a lower value of $K_{m}(0.360 \mu \mathrm{mol} / \mathrm{mL})$ relative to those obtained at $200 \mathrm{rpm}$ and relative to those of the free CALA. sdCALA retained over $80 \%$ of its activity after treatment at $70{ }^{\circ} \mathrm{C}$ for $30 \mathrm{~min}$, but its activity decreased rapidly when the temperature was above $80^{\circ} \mathrm{C}$. The specific activity of sdCALA decreased in the presence of acetonitrile and acetone relative to that of the control (50\% ethanol), regardless of the solvent concentration. The highest activity $(0.67 \mathrm{U} / \mathrm{mL})$ was obtained when the ethanol concentration was $30 \%$.
\end{abstract}

Keywords: Candida antarctica lipase A; surface-display system; shear rate; mass transfer rate; enzymatic kinetic study

\section{Introduction}

Candida antarctica is a psychrophilic Basidiomycetous yeast originally selected from a strain found in Antarctic habitats. This strain expresses two lipolytic enzymes displaying different catalytic properties: Candida antarctica lipase A (CALA) and lipase B (CALB) [1]. CALB, first described in 1994 [2], has a molecular weight of approximately 34-43 kDa. As a result of its high selectivity toward secondary alcohols and its endurance in organic solvents and at high temperatures [2,3], it has been widely applied industrially and academically. The structure of CALA was solved using X-ray crystallography [2,4], with a molecular weight of approximately 45-53 kDa. Compared with CALB, the properties of CALA have been less well explored. CALA displays specific hydrolytic properties; for example, it retains its activity at high temperature $\left(>70^{\circ} \mathrm{C}\right)$ and in acidic environments. In addition, CALA preferentially hydrolyzes triglycerides at position sn-2, which is located at the center of the carbon chain; therefore, it has been applied in the preparation of fat substitutes and to the development of new modes of drug delivery [5]. At present, other microorganisms known to 
produce CALA include Aspergillus sp. [6] and Pichia sp. [2,7] fungi and prokaryotic E. coli [8]. Studies of CALA have mainly been focused on its use in different host cells [9], food processing [10], and transesterification $[10,11]$. To render CALA more applicable, new processes should be developed for its rapid and efficient production.

In 1985, Smith inserted the recombinant antigens to the $\mathrm{N}$-terminus of the filamentous bacteriophage coat protein pIII and expressed them on the phage surface [12]. Many carrier proteins have been demonstrated to carry the protein outside the membranes of cells. Common carrier proteins include S-layer protein, lipoprotein, bacterial fimbriae, and ice nucleation protein (INP) $[10,13,14]$. A variety of biotechnological processes and materials-for example, antibody production, bioconversion, biosensors, bioadsorbents, and oral vaccines-have adopted this technique for process improvement $[13,14]$.

INP is a membrane-bound protein that is capable of binding to the phospholipids of cell membranes $[15,16]$. The main structure of INP can be divided into three parts: the N-terminus, a hydrophobic region that binds to the phospholipids of the outer membrane; an intermediate region, comprising mainly AlaGlyTyrGlySerThrLeuThr (AGYGSTLT) repeat fragments that form an ice core; and the $\mathrm{C}$-terminus, which is a hydrophilic region that can link with the target protein and expose it to the outer membrane surface. INP-based systems can suitably express recombinant protein molecules after modulating the length of the intermediate repeat region, thereby minimizing the issue of steric disorder [17]. According to its genotypes, INP can be classified into four systems: inaK [18], inaQ [19], inaV [20], and inaX [21]. The expression of INP is most stable during the stationary phase of culturing. INP-based systems are among the most useful for Gram-negative bacteria surface-display applications [18].

Many genetic engineering technologies require cell surface carriers for the rapid expression of foreign proteins. Through the surface expression of lipases, for example, various surface-display lipases have been developed with the goal of applying them directly to lipolytic reactions. Matsumoto et al. constructed a yeast cell surface-display system for lipase expression, using a flocculation functional domain of Flo1p as the carrier [22]. Moura et al. assessed the biochemical features of lipase B when immobilized on the cell surface of the methylotrophic yeast Pichia pastoris, using the yeast surface-display approach [23]. Liu et al. displayed lipase Lip2 from Yarrowia lipolytica on the cell surface of Saccharomyces cerevisiae, using Cwp2 as an anchor protein; the thermostability of the displayed lipase was superior to that of free lipase Lip2 [24].

The use of recombinant E. coli to express intracellular target proteins is common. The main issue hindering its application has been the separation and purification of the target protein from the harvested cultural broth-a tedious and labor-intensive process that increases the complexity of production. Surface-display systems could provide an alternative means of obtaining enzymes for direct industrial applications. Wilhelm et al. demonstrated that the cell surface-display protein LipH from P. aeruginosa could properly express foldase-lipase complexes on the surface of E. coli cells [25]. Jo et al. displayed the lipase from Bacillus licheniformis ATCC14580 on the cell surface of E. coli by using Lpp'OmpA as the anchoring protein; this development suggested that E. coli, through the direct display of lipase on its cell membrane, could be applied as a whole cell biocatalyst [26].

In this present study, we constructed an INP surface-display system to express lipase A in the E. coli outer membrane. Although some articles describe the expression of lipase anchoring on the E. coli cell membrane $[25,26]$, those studies did not focus on the effects of cultivation on the biochemical features of surface-display CALA (sdCALA). For example, mass transfer and shear stress during cultivation might directly affect the properties of the enzyme through its exposure to the outside environment. To test this concept, here we performed a preliminary comparison of the biochemical properties of CALA produced intracellularly with those of sdCALA anchored on the membrane. In addition, we also evaluated the kinetic properties of sdCALA prepared under various cultivation conditions. 


\section{Results and Discussion}

\subsection{Gene Construction and Protein Expression}

The host strains E. coli JM109 (DE3)/pET22b-calawt and E. coli JM109 (DE3)/pINP-CALA were constructed according to the methods listed in Section 3.2. Both types of cells were cultivated and induced according to the methods listed in Section 3.3. To obtain the intracellular CALA, the cells were disrupted through sonication, followed by centrifugation to collect the supernatant containing CALA. To obtain sdCALA, the collected cells were dissolved in the same volume of sodium phosphate buffer ( $\mathrm{pH}$ 6.0) for further use. Sodium dodecyl sulfate-polyacrylamide gel electrophoresis (SDS-PAGE) was performed to check for the correct expression of intracellular and surface-display CALA (Figure 1). In the PAGE gel, a band in Lane 1 revealed the successful expression of CALA (53 kDa) and that the expression was mainly intracellular as the soluble protein (Lane 2). In addition, no clear band at $53 \mathrm{kDA}$ appeared in the pellets (Lane 3), implying that no inclusion body was formed. For the surface expression system, a band for INP-CALA ( $80 \mathrm{kDa}$ ) appeared in Lane 4, confirming the accurate expression of the fusion protein INP-CALA (Lane 4), with the main expression located at the pellet (Lane 6) with only a very unclear band in Lane 5 . Thus, the expression of sdCALA occurred mainly on the cell pellet.

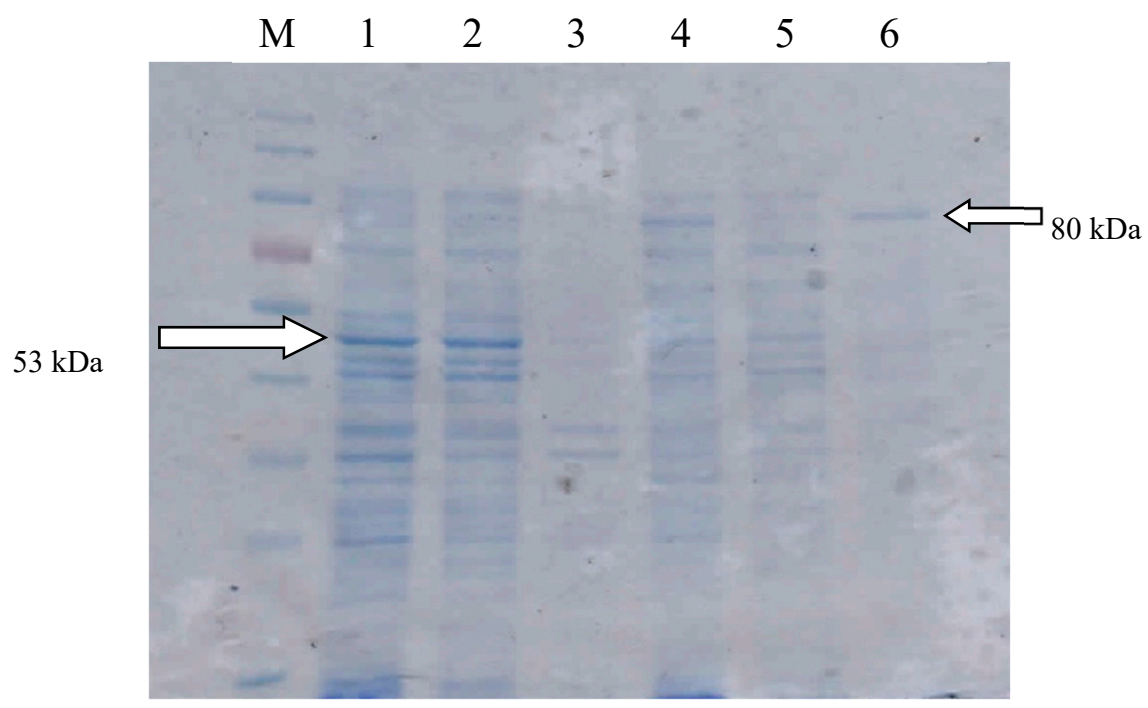

Figure 1. SDS-PAGE of intracellular Candida antarctica lipase A (CALA) and surface-display CALA. Lane M: Marker; Lanes 1-3: Whole cells, supernatant, and pellet of intracellular CALA, respectively; Lanes 4-6: Whole cells, supernatant, and pellet for surface-display CALA (sdCALA), respectively.

The activities of the CALA enzymes obtained from the two systems were assayed (Table 1). The activity of CALA obtained from the intracellular system was approximately $0.326 \mathrm{U} / \mathrm{mL}$, while that from the surface expression system was $0.285 \mathrm{U} / \mathrm{mL}$. The specific activity of sdCALA $(0.285 \mathrm{U} / \mathrm{mg})$ was larger than that of CALA $(0.251 \mathrm{U} / \mathrm{mg})$. We suspected that sdCALA on the cell membrane might have had a larger space for its proper extension. Although the volumetric activity of the lipase A produced through surface expression was slightly lower than that of the intracellular system, the higher specific activity and avoidance of cell disruption suggest that it might be convenient in certain applications. In addition, we found, interestingly, that a small amount of soluble fusion protein INP-CALA existed in the periplasm, with a relative activity of $0.057 \pm 0.04 \mathrm{U} / \mathrm{mL}$. The total expression of sdCALA with the supernatant plus pellet would compete with that of the intracellular CALA. 
Table 1. Expression and activities of intracellular CALA and surface-displayed CALA.

\begin{tabular}{cccc}
\hline Expression System & Biomass $(\mathrm{mg} / \mathrm{mL})$ & Activity $(\mathrm{U} / \mathrm{mL})$ & Specific Activity $(\mathrm{U} / \mathrm{mg})$ \\
\hline Intracellular $^{\mathrm{a}}$ (pET22b-calawt) & $1.298 \pm 0.232$ & $0.326 \pm 0.11$ & $0.251 \pm 0.047$ \\
Surface display $^{\mathrm{b}}$ (pINP-CALA) & $0.999 \pm 0.052$ & $0.285 \pm 0.07$ & $0.285 \pm 0.013$ \\
\hline
\end{tabular}

a To measure the volumetric activity of CALA, the supernatant obtained as stated in Section 3.3 was used for the assay. ${ }^{b}$ To measure the volumetric activity of sdCALA, the harvested cells were resuspended in the same volume of phosphate buffer ( $\mathrm{pH}$ 6.0) for the assay.

In our laboratory, we have frequently applied INP to expose outer membrane proteins; some papers concerning this approach have been published [27-30]. The most typical use has been in the expression of INP-INT-EGFP (INP-intein-enhanced green fluorescent protein) outside the cell membrane and then, through the self-cleavage of INT, to relieve the EGFP to the supernatant [30]. In such a case, the expression of EGFP as the outer membrane protein would result in a green-colored cell pellet. In addition, this approach has also been used for the expression of D-hydantoinase outside the cell membrane and to simplify the enzyme purification process [28]. Those previous studies demonstrated that INP could be used not only to correctly express the target protein as an outer membrane protein but also to maintain the correct conformation of the protein and its usual activity (measured through a whole-cell activity assay). In this study, we used INP to express lipase A as an outer membrane enzyme and applied a tributyrin agar plate test to demonstrate the existence of outer membrane INP-CALA, as described in Section 3.6. Figure 2 displays the results. In the case of sdCALA, a clear zone formed around the cell colony, which was due to direct hydrolysis of the tributyrin. In contrast, the cells prepared with the intracellular CALA did not form any such clear zone. Thus, the JM109/pINP-CALA system could indeed express sdCALA properly outside the cell membranes.

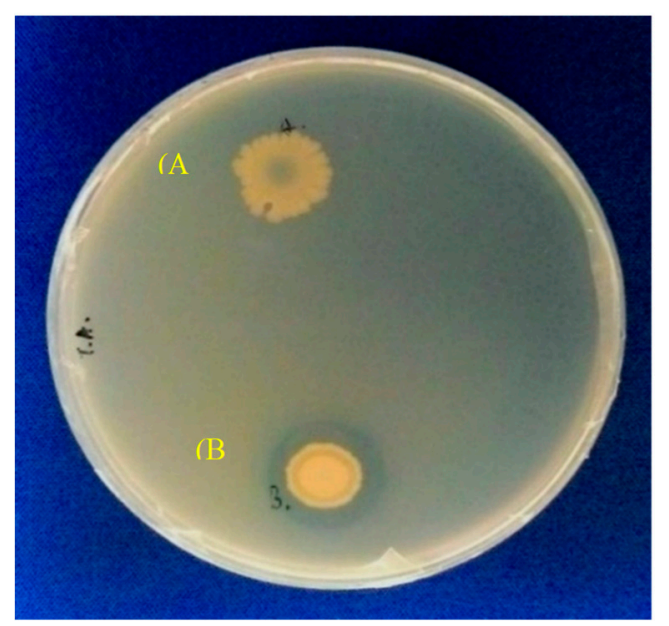

Figure 2. Tributyrin plate tests for intracellular and surface-display CALA. (A: Intracellular CALA; B: sdCALA).

\subsection{Effect of Shaking Rate on sdCALA Activity and Biomass}

Since the expressed sdCALA was anchored outside the cell membrane, the cultivation conditions-especially the shaking rate-would presumably induce various mass transfer rates and shear rates on the produced enzyme. To examine this concept, sdCALA production was performed with cultivation at various shaking rates (Figure 3). The shaking rate did indeed affect the enzyme specific hydrolysis activity and biomass production. The biomass increased remarkably upon increasing the shaking rate from 50 to $100 \mathrm{rpm}$, but the increases were less dramatic thereafter. The specific activity also greatly increased upon increasing the shaking rate from 50 to $100 \mathrm{rpm}$. However, when the shaking rate was at or above $150 \mathrm{rpm}$, the specific activity decreased significantly. To tests the effects of mass transfer and shear on the biomass production and lipase activity, relevant data were 
calculated according to Equations (1)-(5), as described in Section 3.4, and these are listed in Table 2. At the low shaking rate of $50 \mathrm{rpm}$, a low rate of oxygen mass transfer would occur, limiting cell growth and resulting in very low biomass production. This limited oxygen transfer rate would also block the proper expression of sdCALA. When the shaking rate was $100 \mathrm{rpm}$, the higher rate of oxygen mass transfer would benefit cell growth, resulting in a high expression of sdCALA. When the shaking rate was 150-200 rpm, the higher rates of oxygen mass transfer would slightly increase the biomass production, but high shear rates would have a detrimental effect on the expression of sdCALA, due to its direct exposure to the broth. To minimize the damage caused at high shear rates, we selected a shaking rate of $100 \mathrm{rpm}$ for subsequent expressions of sdCALA.

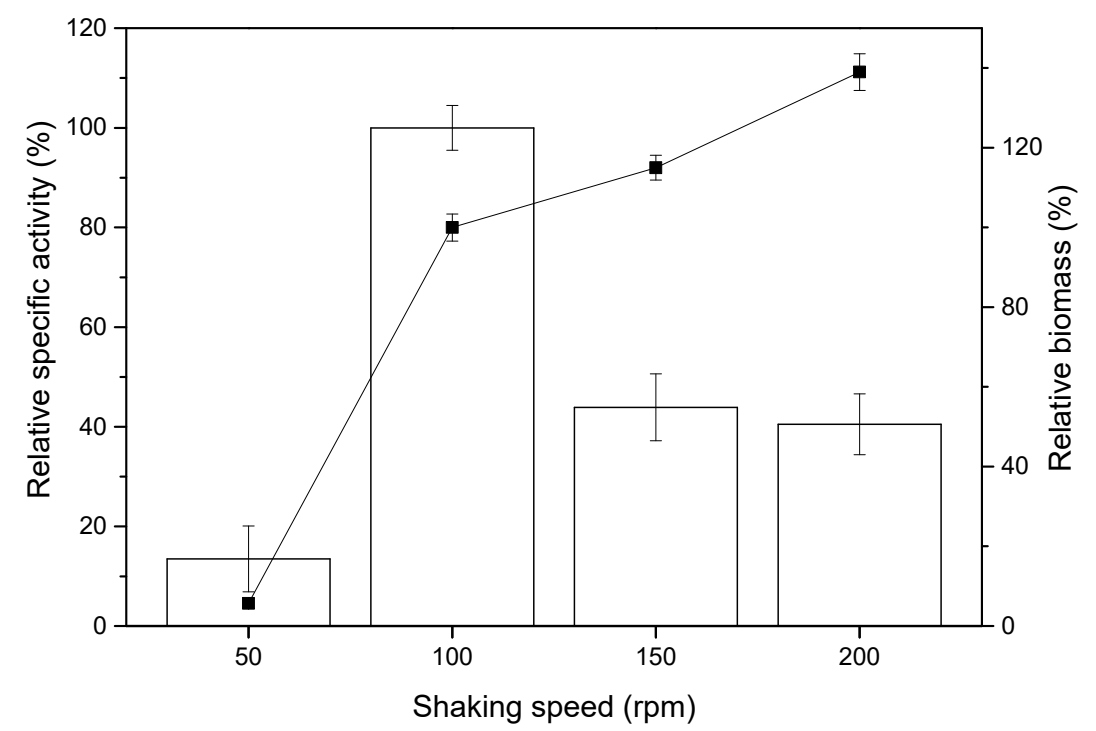

Figure 3. Effect of shaking rate on the specific activity (bars) and biomass production (black squares) of sdCALA. To calculate relative values, the value measured at $100 \mathrm{rpm}$ was set as $100 \%$.

Table 2. Effect of mass transfer and shear rate on the specific activity and biomass production of sdCALA.

\begin{tabular}{ccccc}
\hline Shaking Rate $(\mathbf{r p m})$ & $\left.\boldsymbol{K}_{\boldsymbol{L a}} \mathbf{( h}^{\mathbf{- 1}}\right)$ & $\boldsymbol{\gamma ( \mathbf { h } ^ { \mathbf { 1 } } )}$ & Relative Specific Activity (\%) & Relative Biomass (\%) \\
\hline 50 & 9.6 & 13 & $13.5 \pm 6.6$ & $5.7 \pm 1.2$ \\
100 & 21.4 & 89 & $100 \pm 4.5$ & $100 \pm 3.4$ \\
150 & 34.2 & 276 & $43.9 \pm 6.7$ & $115 \pm 3.1$ \\
200 & 47.8 & 617 & $40.5 \pm 6.1$ & $139 \pm 4.6$ \\
\hline
\end{tabular}

\subsection{Optimal Temperature and $p H$ for Production of CALA and sdCALA}

In reactions involving biocatalysts, the enzyme activity would increase upon increasing the temperature within a certain range. However, the activity would decrease if the temperature was too high, due to the effect of enzyme denaturing. For example, most lipolytic enzymes lose their activity when the temperature exceeds $40^{\circ} \mathrm{C}$ [31]. For CALA, a thermophilic lipolytic enzyme [32,33], the optimal temperature has been reported to be in the range from 50 to $70{ }^{\circ} \mathrm{C}[33,34]$ and possibly even as high as $90^{\circ} \mathrm{C}$ [33]. We prepared two types of sdCALA through the cultivation of JM109/pINP-CALA at 100 and $200 \mathrm{rpm}$ (denoted herein as sdCALA100 and sdCALA200, respectively). As references, we also prepared two samples of intracellular CALA enzymes from cultures of JM109/pET22b-calawt under the same conditions (CALA100 and CALA200, respectively). The activities of all of these tested enzymes were adjusted to $0.35 \mathrm{U} / \mathrm{mL}$ using $50 \mathrm{mM}$ phosphate buffer ( $\mathrm{pH}$ 6).

Figure 4 displays the effect of temperature on the activities of CALA and sdCALA. All of the enzymes exhibited the same profile in response to the temperature. The optimal temperature was 60 
${ }^{\circ} \mathrm{C}$ in each case. Thus, even though they had been subjected to different culture conditions and various expression systems, the resulting enzymes exhibited the same dependency on temperature.

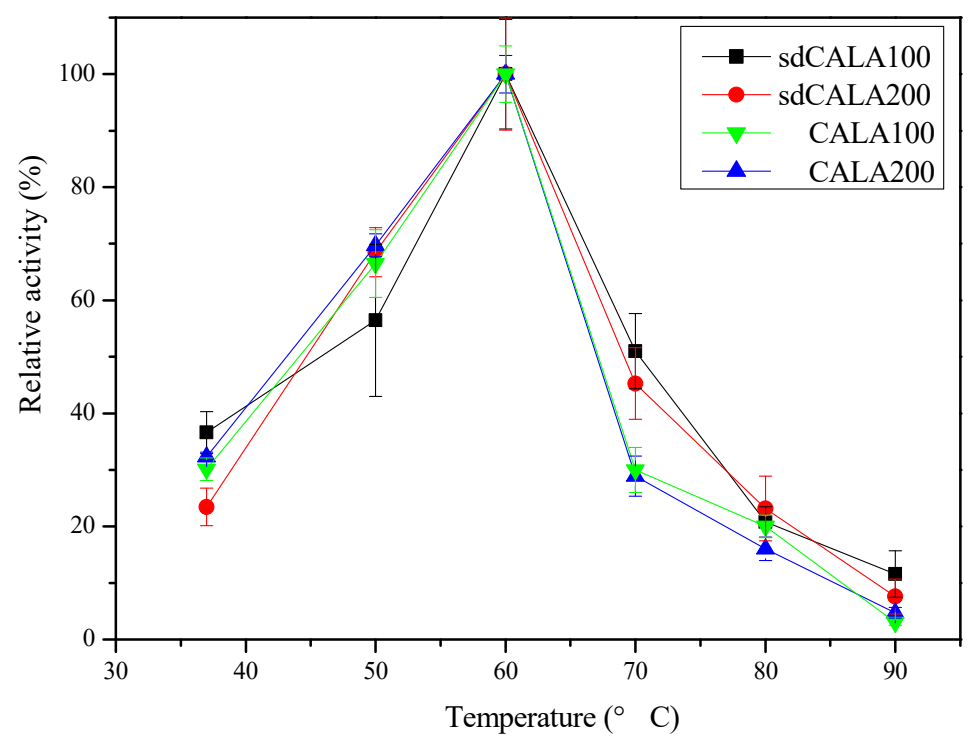

Figure 4. Effect of temperature on the relative activities of samples of CALA and sdCALA prepared at different shaking rates.

Various lipases have their own operating $\mathrm{pH}$ ranges, from as low as $\mathrm{pH} 3$ to as high as $\mathrm{pH} 9[35,36]$. Since the structure of the active site might be affected by the $\mathrm{pH}$, a lipase might display acid- or alkali-resistant properties. Figure 5 displays the effect of $\mathrm{pH}$ on the activities of the CALA and sdCALA samples prepared at the two spinning rates. All of these enzymes had the same $\mathrm{pH}$-dependency, with the optimal activities occurring at $\mathrm{pH} 6$. The activities decreased sharply when the $\mathrm{pH}$ was 7 , and the enzymes were almost inactive at $\mathrm{pH} 9$. Thus, we conclude that CALA is not an alkaline enzyme. Furthermore, the use of different shaking rates for the expression of CALA and sdCALA did not have any effect on their $\mathrm{pH}$ dependency.

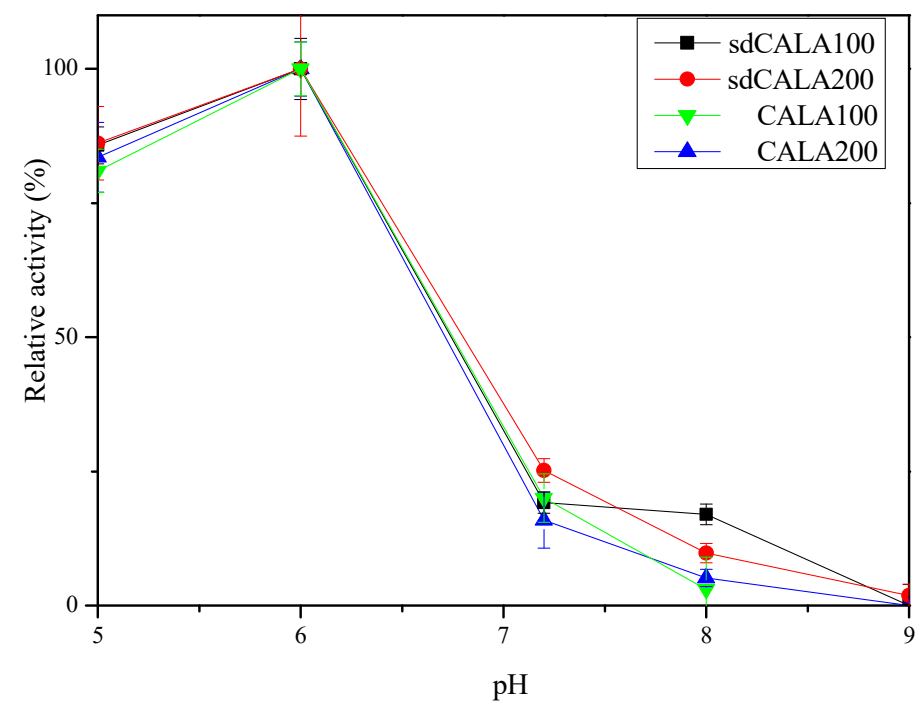

Figure 5. Effect of $\mathrm{pH}$ on the relative activities of CALA and sdCALA samples prepared at different shaking rates. 


\subsection{Kinetic Analyses of Various CALA Enzymes}

We adopted the Michaelis-Menten kinetics model in Equation (6) to test the kinetic behavior of our various lipase A enzymes. Figure 6 presents a Hanes-Woolf plot of the substrate concentration divided by the activity with respect to the substrate concentration (Equation (7)). The kinetic parameters for each enzyme were collected through linear fitting of the data. Table 3 lists the calculated values of $K_{m}$ and $v_{m}$. All of the enzymes displayed values of $v_{m}$ in range of $0.059-0.072(\mu \mathrm{mol} / \mathrm{mL} / \mathrm{min})$ and $K_{m}$ in range of 1.032-1.821 ( $\mu \mathrm{mol} / \mathrm{mL})$, except for sdCALA100, which had a slightly higher value of $v_{m}$ $(0.074 \mu \mathrm{mol} / \mathrm{mL} / \mathrm{min})$ and a much lower value of $K_{m}(0.360 \mu \mathrm{mol} / \mathrm{mL})$. Thus, preparing sdCALA at $100 \mathrm{rpm}$ significantly improved both its reaction rate (high $v_{m}$ ) and substrate affinity (low $K_{m}$ ). The sdCALA obtained at $200 \mathrm{rpm}$ gave a value of $K_{m}$ close to those of the intracellular enzymes. Notably, the collection of intracellular enzymes requires harsh sonication or high pressures for cell disruption, potentially influencing the properties of the enzymes and decreasing the affinity to the substrate. Furthermore, we suspect that sdCALA200, which had been subjected to a higher shaking rate and a higher shear rate, had poorer affinity than sdCALA100 toward the substrate. Therefore, such kinetic analysis can provide indirect evidence for the shear rate affecting the performance of CALA prepared under various cultivation conditions.

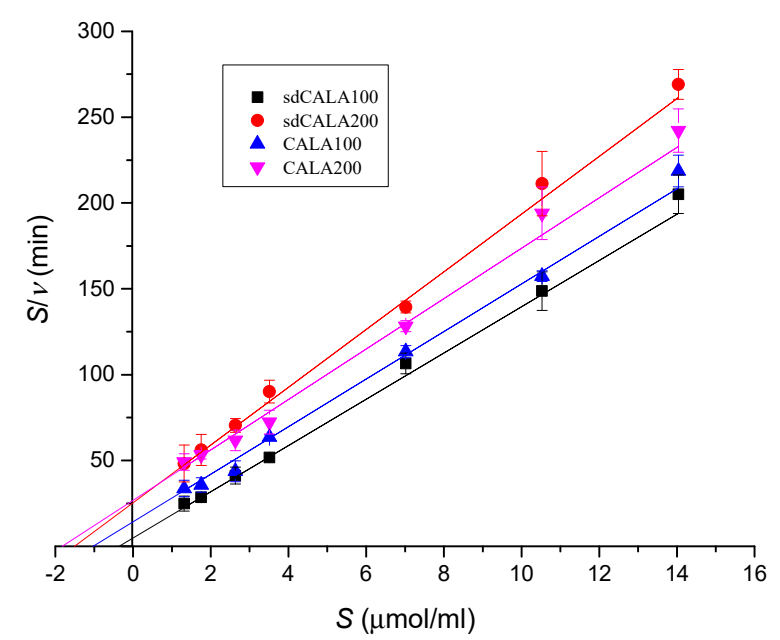

Figure 6. Hanes-Woolf diagram for CALA and sdCALA.

Table 3. Kinetics parameters of CALA and sdCALA.

\begin{tabular}{ccc}
\hline Lipase & $\boldsymbol{v}_{\boldsymbol{m}}(\mu \mathrm{mol} / \mathrm{mL} / \mathrm{min})$ & $\boldsymbol{K}_{m}(\mu \mathrm{mol} / \mathrm{mL})$ \\
\hline sdCALA100 & 0.074 & 0.360 \\
sdCALA200 & 0.059 & 1.510 \\
CALA100 & 0.072 & 1.032 \\
CALA200 & 0.068 & 1.821 \\
\hline
\end{tabular}

\subsection{Thermal Stability of sdCALA}

We tested the thermal stability of sdCALA100 at various temperatures. Samples were taken every $10 \mathrm{~min}$ to obtain the activity assay at the optimal temperature of $60^{\circ} \mathrm{C}$. Figure 7 reveals that sdCALA retained greater than $80 \%$ of its activity when heated at a temperature lower than or equal to $70{ }^{\circ} \mathrm{C}$ for $30 \mathrm{~min}$; however, at $80^{\circ} \mathrm{C}$, its activity dropped remarkably, to less than $20 \%$ after $30 \mathrm{~min}$, and it was almost completely lost after being heated at $90{ }^{\circ} \mathrm{C}$ for $10 \mathrm{~min}$. We found in our earlier study of the optimal temperature that the relative activity of sdCALA decreased to less than $50 \%$ when it was in contact with $50 \%$ ethanol (in the activity assay) at $70{ }^{\circ} \mathrm{C}$ for $5 \mathrm{~min}$; however, in this stability test, greater than $80 \%$ of the residual activity remained after heating at $70{ }^{\circ} \mathrm{C}$ for $30 \mathrm{~min}$ in the absence of contact with ethanol. Thus, a high concentration of ethanol presumably had a negative effect on the activity of 
sdCALA. Accordingly, we tested the influence of various organic solvents at various concentrations on the hydrolysis reactions of sdCALA.

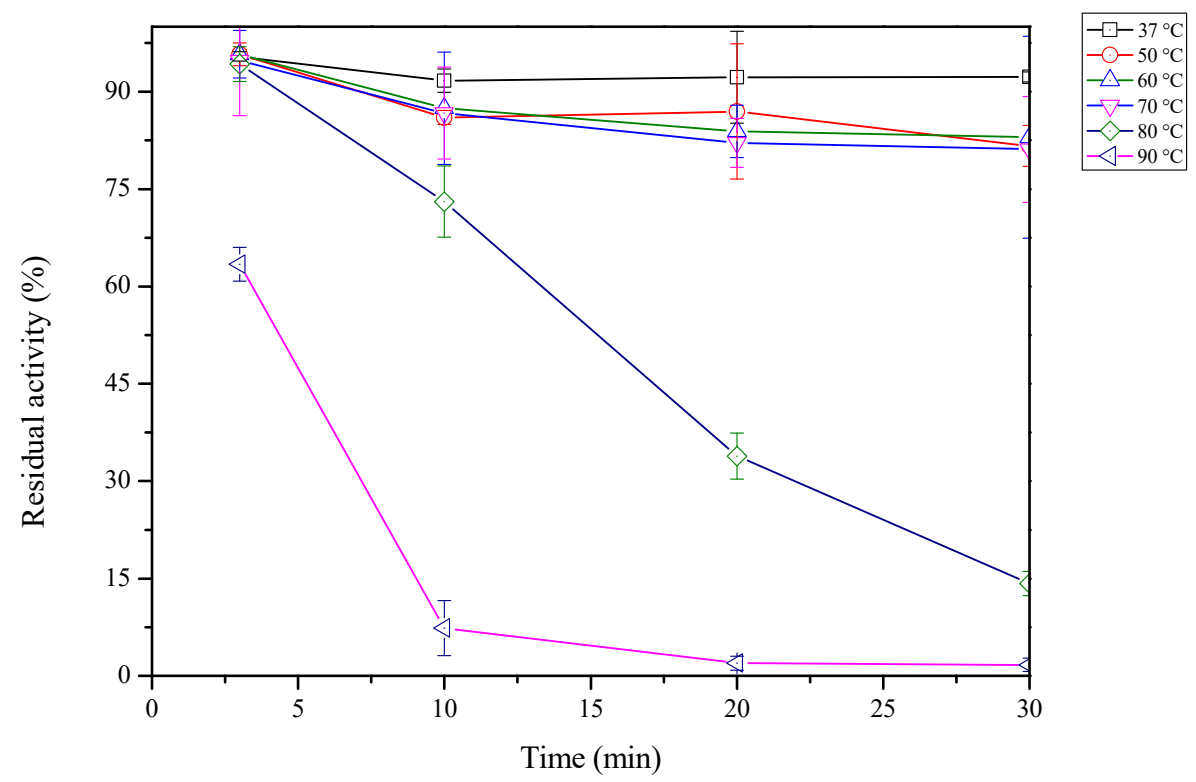

Figure 7. Thermal stability tests for sdCALA, where the initial activity was set as the control.

\subsection{Effect of Organic Solvents on sdCALA Activity}

Yang et al. studied the effects of various organic solvents on the activity of purified CALA produced by Pichia pastoris [37]. They found that when CALA was treated with acetonitrile or acetone, its activities toward esterification and hydrolysis increased. However, when treated with ethanol, only $20 \%$ of the lipolytic activity remained; when treated with isopropanol, $20 \%$ of the hydrolysis and esterification activities were lost.

To explore the effects of organic solvents on sdCALA, we applied ethanol, acetonitrile, acetone, and isopropanol at various concentrations as replacements for 50\% ethanol and analyzed the activities (Figure 8). The activity obtained in the presence of $50 \%$ ethanol was set as the control $(100 \%)$. When the concentration of ethanol decreased to $30 \%$, the activity of sdCALA increased significantly, but it decreased upon lowering the concentration thereafter, which was possibly because of the low solubility of the substrate [ $p$-nitrophenyl palmitate (p-NPP)] at such low concentrations of ethanol. In the case of isopropanol, the activity increased upon decreasing the concentration of the organic solvent, but all of the activities were lower than that of the control ( $50 \%$ ethanol), except when the concentration of isopropanol was at or below $30 \%$. The results obtained when using acetonitrile or acetone were quite different. Increasing the concentration of either of these organic solvents from $20 \%$ to $40 \%$ enhanced the activity, but a concentration of $50 \%$ had a negative effect. Nevertheless, all of the activities in the presence of these two solvents were lower than that of the control. Thus, the results of this study were quite different from those reported by Yang et al. [37]. Presumably, the organic solvents affected the conformation of CALA, exposing its active site more to the substrate. On the other hand, the organic solvents might also have decreased the activities through denaturing of the structure of CALA. In the case of sdCALA, the host $E$. coli might also have been a factor, which was subjected to its own solvent effect-the organic solvents might have varied the cell membrane structure and indirectly affected the structure of the anchored CALA $[38,39]$. A more detailed study of the effect of solvents on hosts would be worthy in future. 


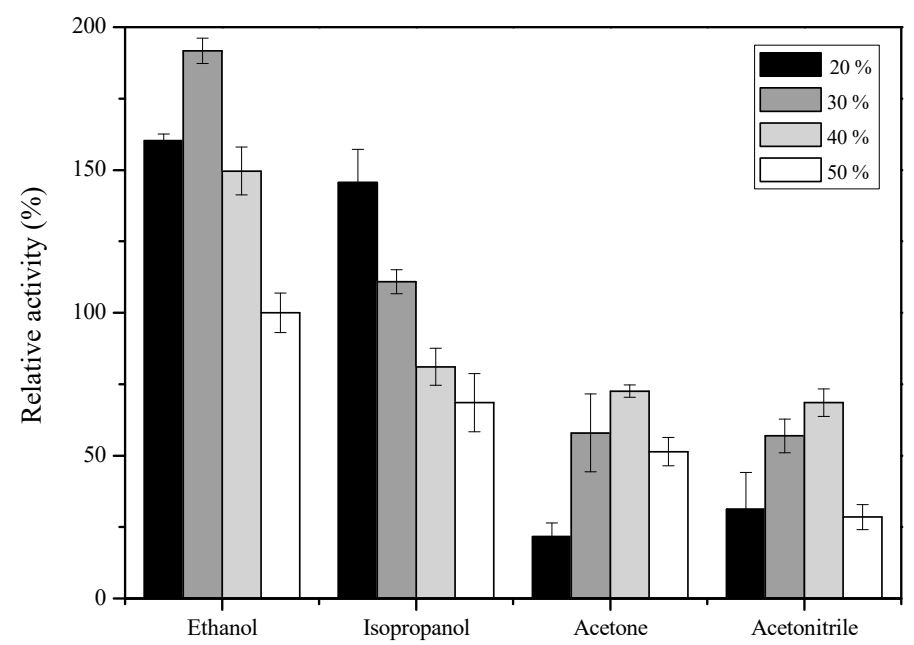

Figure 8. Effect of the concentrations of various organic solvents on the activity of sdCALA with $50 \%$ ethanol set as the control.

\section{Materials and Methods}

\subsection{Strains, Plasmids, and Source}

E. coli DH5 $\alpha$ and E. coli JM109 (DE3) were used as host cells for gene transfer and recombinant protein expression, respectively. The plasmid pET22b-calawt containing the CALA(cala) gene sequence was a gift from Professor Bornscheuer at Greifswald University, Germany; the pET28a-inaX having the INP(inaX) gene was provided by Professor Wen-Teng Wu of National Cen Kong University, Taiwan. The E. coli host strains and vectors used in this study are listed in Table 4. All other chemicals were of analytical grade and obtained from a local supplier.

Table 4. E. coli strains and plasmids used in this study. INP: ice nucleation protein.

\begin{tabular}{ccc}
\hline Strain or Plasmid & Genotype and Relevant Characteristics & Source \\
\hline DH5 $\alpha$ & $\begin{array}{r}\text { F- endA1 glnV44 thi-1 recA1 relA1 gyrA96 } \\
\text { deoR nupG } \Phi 80 \text { dlacZ } \Delta \text { M15 } \\
\Delta(\text { lacZYA-argF)U169, hsdR17(rk }- \text { mk }+), \lambda-\end{array}$ & Novagen \\
\hline JM109 (DE3) & $\begin{array}{r}\text { endA1 glnV44 thi-1 relA1 gyrA96 recA1 } \\
\text { mcrB }+\Delta\left(\text { lac-proAB) e14- }\left(F^{\prime} \text { traD36 proAB+ }\right.\right. \\
\text { lacIq lacZ } \Delta \text { M15) hsdR17(rk }- \text { mk }+) \lambda(\mathrm{DE3})\end{array}$ & NEB \\
\hline pET22b-calawt & CALA (calA) gene fragment in pET22b & $\begin{array}{c}\text { Professor Bornscheuer } \\
\text { (Greifswald University, Germany) }\end{array}$ \\
\hline pET26b-inaX & INP (inaX) gene fragment in pET26b & Professor Wu (NCKU, Taiwan) \\
\hline yT\&A & pBluescript IISK(-) with modified MCS & Yeastern Biotech \\
\hline
\end{tabular}

\subsection{Construction of Expression Systems}

pET22b-calawt was used as the template to amplify the cala gene with restriction sites of EcoRI and XhoI. The primers are listed in Table 5. The obtained inserts (PCR products) were further ligated to vector yT\&A (Yeastern Biotech) to build the constructs of pT-CALA. The cala gene was cut from pT-CALA via the restriction enzyme sites of EcoRI and XhoI and was ligated into pET26b-INP to form the pINP-CALA construct (Figure 9). The production strains were prepared via heat-shock, transforming the respective pET22b-calawt and pINP-CALA into the host E. coli JM109 (DE3). All recombinant DNA manipulations were performed using standard procedures [40]. 
Table 5. Primers used in this study.

\begin{tabular}{ccc}
\hline Primer Name & Primer Sequence (5'3') & Template \\
\hline CALA-F & GAATTCATGCGTGTGAGCCTGCGTAG $(E c o R I)$ & pET22b-calawt \\
CALA-R & CACTCGAGCACCACCACCA $(X h o I)$ & pET22b-calawt \\
\hline
\end{tabular}
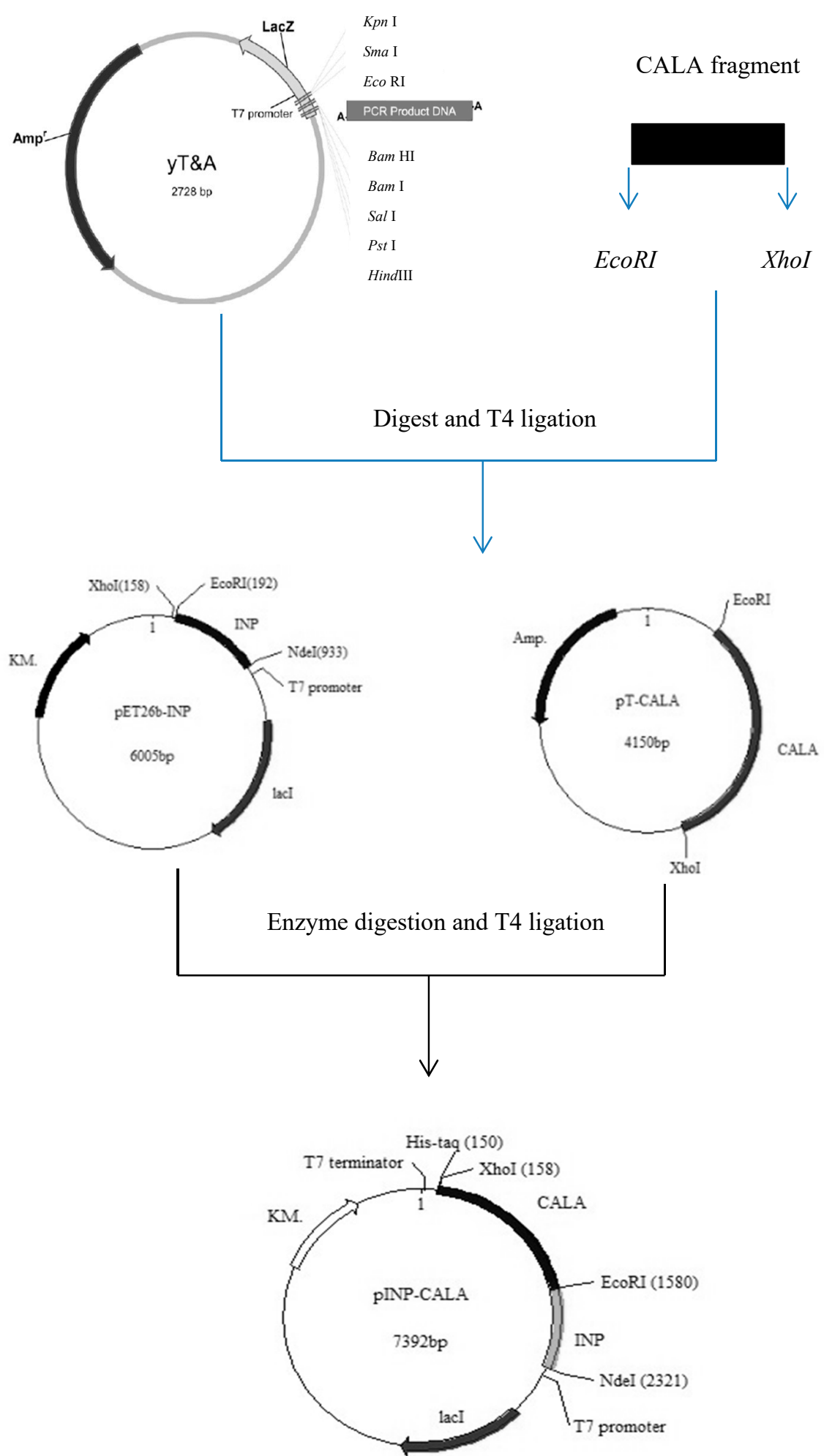

Figure 9. Construction of pINP-CALA. 


\subsection{Cultivation Conditions}

E. coli JM109 strains carrying cala and inaX-cala genes were activated from the preservation freezer to a Petri dish with Luria-Bertani (LB) agar plus $10 \mu \mathrm{L}(50 \mathrm{mg} / \mathrm{mL})$ ampicillin and cultured at $37^{\circ} \mathrm{C}$ for $12 \mathrm{~h}$. A single colony was picked to inoculate $10 \mathrm{~mL}$ LB medium plus $10 \mu \mathrm{L}(50 \mathrm{mg} / \mathrm{mL})$ ampicillin; the culture was operated at $37^{\circ} \mathrm{C}$ and a shaking rate of $200 \mathrm{rpm}$ for $12 \mathrm{~h}$. A volume of $1 \%$ seed culture was used to inoculate $100 \mathrm{~mL}$ of LB medium plus $100 \mu \mathrm{L}(50 \mathrm{mg} / \mathrm{mL})$ ampicillin. Cultivation was conducted at $37^{\circ} \mathrm{C}$ and $200 \mathrm{rpm}$ until the cell optical density $\left(\mathrm{OD}_{600}\right)$ reached 0.8 , followed by the addition of isopropyl $\beta$-D-1-thiogalactopyranoside (IPTG) to a final concentration of $0.1 \mathrm{mM}$. The cultivation temperature and time were set at $15{ }^{\circ} \mathrm{C}$ and $24 \mathrm{~h}$, respectively, while the shaking rate was varied from 50 to $200 \mathrm{rpm}$. To prepare CALA, the broth was centrifuged at $3000 \mathrm{~g}$ for $10 \mathrm{~min}$ to collect the cells. The cells were subjected to sonication disruption (ultrasonic processing at $20 \mathrm{~W}$ for 10 cycles: $30 \mathrm{~s}$ working, $30 \mathrm{~s}$ free) and centrifugation $(10,000 \mathrm{~g}, 10 \mathrm{~min})$ to separate the supernatant from the cell debris pellet. Both samples were subjected to a dyeing process prior to performing the SDS-PAGE assay. The dyeing solution comprised $10 \%$ SDS, $50 \%$ glycerol, $1.5 \mathrm{M}$ Tris- $\mathrm{Cl}$ (pH 6.8), $2 \% \beta$-mercaptoethanol, and $0.5 \%$ bromophenol blue. The samples were mixed with the dyeing solution at a ratio of $5: 1$, followed by heating at $100^{\circ} \mathrm{C}$ for $10 \mathrm{~min}$, to give the loading samples for SDS-PAGE. To prepare the whole-cell sdCALA, centrifugation $(3000 \mathrm{~g}, 10 \mathrm{~min})$ was applied to separate the cells from the broth; the cells were resuspended in phosphate buffer $(\mathrm{pH}$ 6.0) for use in all of the enzyme tests.

\subsection{Estimation of Shear Stress and Mass Transfer Coefficient}

The oxygen mass transfer coefficient $\left(K_{L a}\right)$ for an Erlenmeyer flask can be estimated according to the following equation described by Sanchez et al. [41]:

$$
K_{L a}=0.024 n^{1.16} V_{L}{ }^{-0.83} d_{0}{ }^{0.38} d^{1.92}
$$

where $n$ is the rate (rpm); $V_{L}$ is the liquid volume in the shake flask $(\mathrm{ml}) ; d_{0}$ is the incubator shaking diameter (cm); and $d$ is the maximal diameter of the shake flask (cm). The units of $K_{L a}$ are $\left(\mathrm{h}^{-1}\right)$.

The average shear rate $(\gamma)$ and shear stress $\left(\tau_{t}\right)$ of a liquid in a shake flask can be estimated using the following formulas [42].

$$
\begin{gathered}
\gamma=3600 \frac{\tau_{t}}{\mu_{L}} \\
\tau_{t}=0.0676\left(\frac{d_{p}}{\lambda}\right)^{2}\left(\rho_{L} \mu_{L} \varepsilon\right)^{0.5}
\end{gathered}
$$

where $\rho_{L}$ is the density of the liquid $\left(\mathrm{kg} / \mathrm{m}^{3}\right), \mu_{L}$ is the viscosity of the liquid (Pas), $d_{p}$ is the average cell diameter $(\mathrm{m}), \lambda$ is the Kolmogorov length scale $(\mathrm{m})$, and $\varepsilon$ is the energy dissipation rate $\left(\mathrm{m}^{2} / \mathrm{s}^{3}\right)$, which are calculated from the following equation:

$$
\begin{gathered}
\lambda=\left(\frac{\mu_{L}}{\rho_{L}}\right)^{3 / 4} \varepsilon^{-1 / 4} \\
\varepsilon=\frac{1.94 n^{2.8} d_{S}^{3.6} \mu_{L} 0.2}{V_{L}^{2 / 3} \rho_{L}^{0.2}}
\end{gathered}
$$

where $n$ is the rate $(1 / \mathrm{s}), d_{s}$ is the flask diameter $(\mathrm{m})$, and $V_{L}$ is the working volume of the medium $\left(\mathrm{m}^{3}\right)$. The units of $\gamma$ are $\left(\mathrm{h}^{-1}\right)$; the units of $\tau_{t}$ are $\left(\mathrm{N} / \mathrm{m}^{2}\right)$. 


\subsection{Kinetics Models}

The kinetics were derived from the Michaelis-Menten equation as follows:

$$
v=\frac{v_{m} S}{K_{m}+S}
$$

Rearranging Equation (6) by inversion and multiplication by $S$ yields the Hanes-Woolf equation

$$
\frac{S}{v}=\frac{1}{v_{m}} S+\frac{K_{m}}{v_{m}}
$$

where $S$ is the initial substrate concentration, $v$ is the reaction rate, $K_{m}$ is the Michaelis-Menten constant, and $v_{m}$ is the maximum reaction rate. The Hanes-Woolf equation was applied by plotting $S / v$ with respect to $S$, to yield a straight line of slope $1 / v_{m}$ and an intercept of $K_{m} / v_{m}$.

Lipase hydrolysis reactions were performed to estimate the reaction rate constants. In the tests, the initial activities of CALA and sdCALA were set at $0.35 \mathrm{U} / \mathrm{mL}$, while the concentration of p-NPP was varied from 0.1 to $10 \mathrm{mg} / \mathrm{mL}$ (equivalent to $0.265-26.5 \mu \mathrm{mol} / \mathrm{mL}$ ). The activity measured at $60^{\circ} \mathrm{C}$ and $\mathrm{pH} 6$ was used to represent the sample reaction rate [43].

\subsection{Assays}

Protein analysis was performed using 15\% SDS-PAGE and Coomassie Blue staining [44]. The lipase activity was assayed using the modified method described by Chiou et al. [43]. A 50\% ethanol solution of the reaction mixture was prepared as follows: $0.1 \mathrm{~mL}$ of free lipase was added to a mixture of $1 \mathrm{~mL}$ of $\mathrm{p}-\mathrm{NPP}(5 \mathrm{mg} / \mathrm{mL}$ in $99 \%$ ethanol) and $1 \mathrm{~mL}$ of $50 \mathrm{mM}$ phosphate buffer (pH 6.0), followed by incubating at $60{ }^{\circ} \mathrm{C}$ and $100 \mathrm{rpm}$ for $5 \mathrm{~min}$. The reaction was terminated by adding $0.9 \mathrm{~mL}$ of $0.5 \mathrm{~N} \mathrm{Na}_{2} \mathrm{CO}_{3}$ to a $0.1 \mathrm{~mL}$ sample; all of the samples were centrifuged at $10,000 \mathrm{~g}$ for $15 \mathrm{~min}$. The absorbance of the supernatant at $410 \mathrm{~nm}$ was measured using a UV-Vis spectrophotometer (Beckman DU-530, Fullerton, CA, USA). A molar extinction coefficient for $p$-nitrophenol of $15,000 \mathrm{M}^{-1} \mathrm{~cm}^{-1}$ was used. Unless stated otherwise, one unit (1U) of enzyme activity was defined as the amount of enzyme required to produce $1 \mu \mathrm{mol}$ of $p$-nitrophenol per min at $60^{\circ} \mathrm{C}$ and $\mathrm{pH}$ 6.0.

For the thermal stability tests, $1 \mathrm{~mL}$ of sdCALA $(0.35 \mathrm{U} / \mathrm{mL})$ was heated on an incubator set at $37-90{ }^{\circ} \mathrm{C}$ for $30 \mathrm{~min}$, followed by cooling in an ice bath to remove the residual heat. The sdCALA activity was measured at $60^{\circ} \mathrm{C}$ and $\mathrm{pH} 6$ for $5 \mathrm{~min}$. For the organic solvent tests, the reaction substrate (p-NPP) was dissolved in various concentrations of ethanol, isopropanol, acetone, and acetonitrile, and then the activity was measured at $60^{\circ} \mathrm{C}$ and $\mathrm{pH} 6$ for $5 \mathrm{~min}$. Tributyrin agar plate tests were based on the method described by Jung et al. [45]. A drop $(10 \mu \mathrm{L})$ of the harvested broth was placed on a prepared tributyrin agar plate and left at room temperature for 3 days; then, the clear zone around the tested sample was scrutinized.

\subsection{Statistical Analysis}

To obtain statistical results, all data were analyzed using Origin software (v. 9.0). Experiments were performed in triplicate and data are expressed as means $\pm \mathrm{SD}$; significant differences between means were identified through analysis of variance (Origin software, v.9.0).

\section{Conclusions}

We have observed that the shaking rate has an effect on the production of surface-displayed lipase A. Since sdCALA was exposed outside the cell membrane, an increase in the shaking rate during cultivation had a negative effect on this surface-displayed enzyme. Indeed, the increased shaking rate lowered the specific activity of sdCALA as a result of shear stress. In contrast, the cultivation conditions did not affect the temperature and $\mathrm{pH}$ dependency of CALA and sdCALA. A kinetic study revealed that the cultivation of sdCALA at a moderate shaking rate optimized the hydrolysis performance. 
Furthermore, the observed decrease in the specific activity of sdCALA in the presence of various organic solvents was presumably due to the effect of decomposition of the host cells.

Author Contributions: Data curation and methodology, C.-F.C. and S.-C.L., conceptualization, writing - original draft preparation; writing — review and editing, project administration, T.-Y.J. and Y.-C.L. All authors have read and agreed to the published version of the manuscript.

Funding: This study was supported by research grants from the National Science Council of Taiwan (grant nos. MOST 103-2221-E-005-071-MY3 and MOST 106-2313-B-005-029) and China Medical University (grant nos. CMU108-AWARD-01 and CMU-108-MF-122).

Conflicts of Interest: The authors declare no conflicts of interest.

\section{References}

1. Kirk, O.; Christensen, M.W. Lipases from Candida antarctica: Unique biocatalysts from a unique origin. Org. Process Res. Dev. 2002, 6, 446-451. [CrossRef]

2. Uppenberg, J.; Parkar, S.; Bergfors, T.; Jones, T.A. Crystallization and preliminary X-ray studies of lipase B from Candida antarctica. J. Mol. Biol. 1994, 235, 790-792. [CrossRef] [PubMed]

3. Blank, K.; Morfill, J.; Gumpp, H.; Gaub, H.E. Functional expression of Candida antarctica lipase B in Eschericha coli. J. Biotechnol. 2006, 125, 474-483. [CrossRef] [PubMed]

4. Widmann, M.; Juhl, P.B.; Pleiss, J. Structural classification by the lipase engineering database: A case study of Candida antarctica lipase A. BMC Genom. 2010, 11, 123-131. [CrossRef]

5. de María, P.D.; Carboni-Oerlemans, C.; Tuin, B.; Bargeman, G.; van der Meer, A.; van Gemert, R. Biotechnological applications of Candida antarctica lipase A: State-of-the-art. J. Mol. Catal. B-Enzym. 2005, 37, 36-46. [CrossRef]

6. Hoegh, I.; Patkar, S.; Halkier, T.; Hansen, M.T. Two lipases from Candida antarctica: Cloning and expression in Aspergillus oryzae. Can. J. Bot. 1995, 73, 869-875. [CrossRef]

7. Pfeffer, J.; Richter, S.; Nieveler, J.; Hansen, C.E.; Rhlid, R.B.; Schmid, R.D.; Rusnak, M. High yield expression of lipase A from Candida antarctica in the methylotrophic yeast Pichia pastoris and its purification and characterisation. Appl. Microbiol. Biotechnol. 2006, 72, 931-938. [CrossRef]

8. Pfeffer, J.; Rusnak, M.; Hansen, C.-E.; Rhlid, R.B.; Schmid, R.D.; Maurer, S.C. Functional expression of lipase A from Candida antarctica in Escherichia coli-A prerequisite for high-throughput screening and directed evolution. J. Mol. Catal. B-Enzym. 2007, 45, 62-67. [CrossRef]

9. Larsen, M.W.; Bornscheuer, U.T.; Hult, K. Expression of Candida antarctica lipase B in Pichia pastoris and various Escherichia coli systems. Protein Expr. Purif. 2008, 62, 90-97. [CrossRef]

10. Larios, A.; Garcia, H.S.; Oliart, R.M.; Valerio-Alfaro, G. Synthesis of flavor and fragrance esters using Candida antarctica lipase. Appl. Microbiol. Biotechnol. 2004, 65, 373-376. [CrossRef]

11. Ognjanovic, N.; Bezbradica, D.; Knezevic-Jugovic, Z. Enzymatic conversion of sunflower oil to biodiesel in a solvent-free system: Process optimization and the immobilized system stability. Bioresour. Technol. 2009, 100, 5146-5154. [CrossRef]

12. Smith, G.P. Filamentous fusion phage-novel expression vectors that display cloned antigens on the virion surface. Science 1985, 228, 1315-1317. [CrossRef] [PubMed]

13. Lee, S.Y.; Choi, J.H.; Xu, Z. Microbial cell-surface display. Trends Biotechnol. 2003, 21, 45-52. [CrossRef]

14. Wernerus, H.; Stahl, S. Biotechnological applications for surface engineered bacteria. Biotechnol. Appl. Biochem. 2004, 40, 209-228. [PubMed]

15. Margaritis, A.; Bassi, A.S. Principles and biotechnological applications of bacterial ice nucleation. Crit. Rev. Biotechnol. 1991, 11, 277-295. [CrossRef] [PubMed]

16. Edwards, A.R.; Van Den Bussche, R.A.; Wichman, H.A.; Orser, C.S. Unusual pattern of bacterial ice nucleation gene evolution. Mol. Biol. Evol. 1994, 11, 911-920.

17. van Bloois, E.; Winter, R.T.; Kolmar, H.; Fraaije, M.W. Decorating microbes: Surface display of proteins on Escherichia coli. Trends Biotechnol. 2011, 29, 79-86. [CrossRef]

18. Samuelson, P.; Gunneriusson, E.; Nygren, P.A.; Stahl, S. Display of proteins on bacteria. J. Biotechnol. 2002, 96, 129-154. [CrossRef]

19. Li, Q.; Yu, Z.; Shao, X.; He, J.; Li, L. Improved phosphate biosorption by bacterial surface display of phosphate binding protein utilizing ice nucleation protein. FEMS Microbiol. Lett. 2009, 299, 44-52. [CrossRef] 
20. Shimazu, M.; Mulchandani, A.; Chen, W. Cell surface display of organophosphorus hydrolase using ice nucleation protein. Biotechnol. Prog. 2001, 17, 76-80. [CrossRef]

21. Wu, P.H.; Giridhar, R.; Wu, W.T. Surface display of transglucosidase on Escherichia coli by using the ice nucleation protein of Xanthomonas campestris and its application in glucosylation of hydroquinone. Biotechnol. Bioeng. 2006, 95, 1138-1147. [CrossRef] [PubMed]

22. Matsumoto, T.; Fukuda, H.; Ueda, M.; Tanaka, A.; Kondo, A. Construction of yeast strains with high cell surface lipase activity by using novel display systems based on the Flo1p flocculation functional domain. Appl. Environ. Microbiol. 2002, 68, 4517-4522. [CrossRef] [PubMed]

23. Moura, M.V.H.; Silva, G.P.D.; Machado, A.C.D.O.; Torres, F.A.G.; Freire, D.M.G.; Almeida, R.V. Displaying lipase B from Candida antarctica in Pichia pastoris using the yeast surface display approach: Prospection of a new anchor and characterization of the whole cell biocatalyst. PLoS ONE 2015, 12, e0141454. [CrossRef] [PubMed]

24. Liu, W.; Zhao, H.; Jia, B.; Xu, L.; Yan, Y. Surface display of active lipase in Saccharomyces cerevisiae using Cwp2 as an anchor protein. Biotechnol. Lett. 2010, 32, 255-260. [CrossRef]

25. Wilhelm, S.; Rosenau, F.; Becker, S.; Buest, S.; Hausmann, S.; Kolmar, H.; Jaeger, K.-E. Functional cell-surface display of a lipase-specific chaperone. Chembiochem 2007, 8, 55-60. [CrossRef]

26. Jo, J.-H.; Han, C.-W.; Kim, S.-H.; Kwon, H.-J.; Lee, H.-H. Surface display expression of Bacillus licheniformis lipase in Escherichia coli using Lpp'OmpA Chimera. J. Microbiol. 2014, 52, 856-862. [CrossRef]

27. Kan, S.-C.; Chen, C.-M.; Lin, C.-C.; Wu, J.-Y.; Shieh, C.-J.; Liu, Y.-C. Deciphering EGFP production via surface display and self-cleavage intein system in different hosts. J. Taiwan Inst. Chem. Eng. 2015, 55, 1-6. [CrossRef]

28. Lin, C.-C.; Liu, T.-T.; Kan, S.-C.; Zang, C.-Z.; Yeh, C.-W.; Wu, J.-Y.; Chen, J.-H.; Shieh, C.-J.; Liu, Y.-C. Production of D-Hydantoinase via surface display and self-cleavage system. J. Biosci. Bioeng. 2013, 116, 562-566. [CrossRef]

29. Wu, J.-Y.; Chen, C.-I.; Chen, C.-M.; Lin, C.-C.; Kan, S.-C.; Shieh, C.-J.; Liu, Y.-C. Cell disruption enhanced the pure EGFP recovery from an EGFP-intein- surface protein production system in recombinant E. coli. Biochem. Eng. J. 2012, 68, 12-18. [CrossRef]

30. Wu, J.-Y.; Tsai, T.-Y.; Liu, T.-T.; Lin, C.-C.; Chen, J.-H.; Yang, S.-C.; Shieh, C.-J.; Liu, Y.-C. Production of recombinant EGFP via surface display of ice nucleation protein and self-cleavage intein. Biochem. Eng. J. 2011, 54, 158-163. [CrossRef]

31. Shamel, M.M.; Ramachandran, K.B.; Hasan, M. Operational stability of lipase enzyme: Effect of temperature and shear. Dev. Chem. Eng. Min. Process. 2005, 13, 599-604. [CrossRef]

32. Dimitrijevic, A.; Velickovic, D.; Bihelovic, F.; Bezbradica, D.; Jankov, R.; Milosavic, N. One-step, inexpensive high yield strategy for Candida antarctica lipase A isolation using hydroxyapatite. Bioresour. Technol. 2012, 107, 358-362. [CrossRef] [PubMed]

33. Zamost, B.L.; Nielsen, H.K.; Starnes, R.L. Thermostable enzymes for industrial applications. J. Ind. Microbiol. 1991, 8, 71-81. [CrossRef]

34. Panpipat, W.; Xu, X.; Guo, Z. Improved acylation of phytosterols catalyzed by Candida antarctica lipase A with superior catalytic activity. Biochem. Eng. J. 2013, 70, 55-62. [CrossRef]

35. Boran, R.; Ugur, A. Partial purification and characterization of the organic solvent-tolerant lipase produced by Pseudomonas fluorescens RB02-3 isolated from milk. Prep. Biochem. Biotechnol. 2010, 40, 229-241. [CrossRef] [PubMed]

36. El-Batal, A.I.; Farrag, A.A.; Elsayed, M.A.; El-Khawaga, A.M. Effect of environmental and nutritional parameters on the extracellular lipase production by Aspergillus niger. Int. Lett. Nat. Sci. 2016, 60, 18-29. [CrossRef]

37. Yang, C.; Wang, F.; Lan, D.; Whiteley, C.; Yang, B.; Wang, Y. Effects of organic solvents on activity and conformation of recombinant Candida antarctica lipase A produced by Pichia pastoris. Process Biochem. 2012, 47, 533-537. [CrossRef]

38. Ramos, J.L.; Duque, E.; Rodríguez-Herva, J.J.; Godoy, P.; Haïdour, A.; Reyes, F.; Fernández-Barrero, A. Mechanisms for solvent tolerance in bacteria. J. Biol. Chem. 1997, 272, 3887-3890. [CrossRef]

39. Segura, A.; Duque, E.; Mosqueda, G.; Ramos, J.L.; Junker, F. Multiple responses of Gram-negative bacteria to organic solvents. Environ. Microbiol. 1999, 1, 191-198. [CrossRef]

40. Sambrook, J.; Russel, D.W. Molecular Cloning: A Laboratory Manual, 3rd ed.; Cold Spring Harbor Laboratory Press: New York, NY, USA, 2001. 
41. Sanchez, C.E.G.; Martınez-Trujillo, A.; Osorio, G.A. Oxygen transfer coefficient and the kinetic parameters of exo-polygalacturonase production by Aspergillus flavipes FP-500 in shake flasks and bioreactor. Lett. Appl. Microbiol. 2012, 55, 444-452. [CrossRef]

42. Camacho, F.G.; Rodriguez, J.J.G.; Miron, A.S.; Garcıa, M.C.C.; Belarbi, E.H.; Grima, E.M. Determination of shear stress thresholds in toxic dinoflagellates cultured in shaken flasks Implications in bioprocess engineering. Process Biochem. 2007, 42, 1506-1515. [CrossRef]

43. Chiou, S.H.; Wu, W.T. Immobilization of Candida rugosa lipase on chitosan with activation of the hydroxyl groups. Biomaterials 2004, 25, 197-204. [CrossRef]

44. Laemmli, U.K. Cleavage of structural proteins during the assembly of the head of bacteriophage T4. Nature 1970, 227, 680-685. [CrossRef] [PubMed]

45. Jung, H.C.; Ko, S.; Ju, S.J.; Kim, E.J.; Kim, M.K.; Pan, J.G. Bacterial cell surface display of lipase and its randomly mutated library facilitates high-throughput screening of mutants showing higher specific activities. J. Mol. Catal. B-Enzym. 2003, 26, 177-184. [CrossRef]

(C) 2020 by the authors. Licensee MDPI, Basel, Switzerland. This article is an open access article distributed under the terms and conditions of the Creative Commons Attribution (CC BY) license (http://creativecommons.org/licenses/by/4.0/). 